MA'ALIM: Jurnal Pendidikan Islam

Volume 1, Nomor 1, Juli 2020

\title{
PERAN PENGAWAS PENDIDIKAN AGAMA ISLAM (PPAI) DALAM MENINGKATKAN KOMPETENSI GURU PAI DI SMP SWASTA WILAYAH KECAMATAN SIDOARJO KABUPATEN SIDOARJO
}

\author{
Laila Nuzulul Fitria Noor \\ IAIN Ponorogo \\ lailanfnoor@gmail.com
}

\author{
Kharisul Wathoni \\ IAIN Ponorogo \\ kharisulwathoni73@gmail.com
}

\begin{abstract}
Supervisor of Islamic Education is one component that has an important role in improving the quality of education. The tasks of the supervisor of Islamic education is to improve the competence of Islamic education teachers in schools to produce quality and professional teachers. This study aims to determine what is the role of Islamic education supervisors in improving pedagogical competence and professional competence of Islamic education teachers in Private Junior High School in District of Sidoarjo, Sidoarjo. The researcher used a qualitative approach with collection data methods such as interviews, observation, and documentation. Data analysis method used an interactive model (plot) of Miles and Huberman which includes data reduction, data display, and conclusion or verification. From the results of the study it was found that the role of the supervisor of Islamic education in improving the pedagogical competence of Islamic Education teachers in Private Junior High School in District of Sidoarjo, Sidoarjo had been done well through several ways such as supervision in learning planning, ability in student learning processes and outcomes, ability to utilize resources learning, the ability to develop student potential. Whereas the role of the supervisor of Islamic education in enhancing the professional competence of Islamic Education teachers in Private Junior High School in District of Sidoarjo, Sidoarjo has been fulfilled through several ways, namely providing assistance for teachers in preparing RPP and monitoring of teaching and learning activities in the classroom.
\end{abstract}

Keywords: Islamic education, teacher, teacher competence, teacher supervision.

Abstrak: Pengawas Pendidikan Agama Islam merupakan salah satu komponen yang berperan dalam meningkatkan kualitas pendidikan. Salah satu tugas pengawas pendidikan agama Islam adalah meningkatkan kompetensi guru pendidikan agama Islam di sekolah untuk menghasilkan guru yang berkualitas dan profesional. Penelitian ini bertujuan untuk mengetahui bagaimana peran pengawas pendidikan agama Islam dalam meningkatkan kompetensi pedagogik dan kompetensi profesional guru Pendidikan agama Islam di SMP Swasta Wilayah Kecamatan Sidoarjo Kabupaten Sidoarjo. Peneliti menggunakan pendekatan kualitatif dengan metode pengumpulan berupa wawancara, observasi, dan dokumentasi. Metode analisis datanya menggunakan model interaktif (alur) Miles dan Huberman yang mencakup reduksi data, display data, dan pengambilan kesimpulan atau verifikasi, sehingga data yang didapatkan mendalam dan interaktif. Dari hasil penelitian ditemukan bahwa peran pengawas pendidikan agama Islam dalam meningkatkan kompetensi pedagogik guru PAI di SMP Swasta Wilayah Kecamatan Sidoarjo Kabupaten Sidoarjo sudah dilakukan dengan baik melalui beberapa cara seperti supervisi dalam perencanaan pembelajaran, kemampuan dalam proses dan hasil belajar siswa, kemampuan memanfaatkan sumber-sumber belajar, kemampuan membina potensi siswa. Sedangkan peran pengawas 
MA'ALIM: Jurnal Pendidikan Islam

Volume 1, Nomor 1, Juli 2020

pendidikan agama Islam dalam meningkatkan kompetensi profesional guru PAI di SMP Swasta Wilayah Kecamatan Sidoarjo Kabupaten Sidoarjo sudah terpenuhi melalui beberapa cara yaitu melakukan pendampingan bagi guru dalam menyusun RPP dan monitoring terhadap kegiatan belajar mengajar di kelas.

Kata kunci: Guru, kompetensi guru, pendidikan agama Islam, supervisi guru.

\section{PENDAHULUAN}

Fungsi dan tujuan pendidikan di Indonesia seperti yang tertuang pada Bab II pasal 3 Undang-undang Republik Indonesia Nomor 20 Tahun 2003 tentang Sistem Pendidikan Nasional adalah mengembangkan kemampuan dan membentuk watak serta peradaban bangsa yang bermartabat dalam rangka mencerdaskan kehidupan bangsa, bertujuan untuk berkembangnya potensi peserta didik agar menjadi manusia yang beriman dan bertakwa kepada Tuhan Yang Maha Esa, berakhlak mulia, sehat, berilmu, cakap, kreatif, mandiri, dan menjadi warga nagara yang demokratis serta bertanggung jawab ${ }^{1}$. Tujuan tersebut dapat tercapai dengan adanya pendidikan, yang mana pendidikan sebagai usaha membina dan mengembangkan aspek-aspek rohaniah dan jasmaniah juga harus berlangsung secara bertahap. Suatu proses yang digunakan dalam usaha kependidikan adalah proses yang terarah dan bertujuan, yaitu mengarahkan anak didik (manusia) kepada titik optimal kemampuanya. Keberhasilan sebuah lembaga pendidikan tidak ditentukan oleh beberapa faktor saja, namun banyak faktor yang mempengaruhinya. Salah satu faktor tersebut adalah kegiatan monitoring dan controlling atau dengan kata lain pengawasan seluruh komponen dan aktivitas akademik adalah kegiatan yang sangat krusial, untuk meningkatkan mutu pendidikan di Sekolah / Madrasah.

Pengawasan merupakan fungsi akademik dan fungsi administrasi yang tergolong pokok dan penting. Pengawasan juga merupakan kegiatan administrasi yang dilakukan setelah perencanaan dan pengorganisasian. Pengawasan sering dimaknai dengan beberapa pengertian antara lain, pengontrolan (controlling), pengendalian, pengarahan, dan sebagainya. Pengawasan memiliki arti menguji, memeriksa, memverifikasi atau bahkan mengecek apakah segala sesuatu yang terjadi sudah sesuai dengan rencana, instruksi yang dikeluarkan, atau prinsip dan asas yang telah ditetapkan atau dibakukan. ${ }^{2}$ Peran pengawas dalam melaksanakan tugas-tugas kependidikan

\footnotetext{
${ }^{1}$ Undang-Undang RI, Sistem Pendidikan Nasional (Jakarta: Depdiknas, 2004), 4.

2 Departemen Agama RI, Profesionalisme Pelaksanaan Pengawasan Pendidikan (Jakarta: DIRJEND Kelembagaan Agama Islam, 2005), 31.
} 
MA'ALIM: Jurnal Pendidikan Islam

Volume 1, Nomor 1, Juli 2020

dan pembelajaran di sekolah bukan saja sebagai seorang supervisor pendidikan, namun ia juga sebagai konselor dan motivator agar dapat menciptakan suasana kondusif dalam proses belajar mengajar di sekolah.

Tugas pokok pengawas sekolah berdasarkan Peraturan Menteri Negara Aparatur Negara dan Reformasi Birokerasi Nomor 21 tahun 2010 pasal 5 adalah melaksanakan kegiatan pengawasan akademik dan pengawasan manajerial pada satuan pendidikan yang meliputi penyusunan program pengawasan, pelaksanaan pembinaan, pemantauan pelaksanaan 8 (delapan) Standar Nasional Pendidikan, penilaian, pembimbingan dan pelatihan professional guru dan evaluasi hasil pelaksanaan program pengawasan, dan pelaksanaan tugas kepengawasan di daerah khusus. ${ }^{3}$

Pengawas sekolah menurut Peraturan Menteri Agama (PMA) No. 2 Tahun 2012 tentang Pengawas Madrasah dan Pengawas Pendidikan Agama Islam pada Sekolah yang telah diubah oleh PMA No. 31 Tahun 2013 tentang Perubahan Peraturan Menteri Agama Republik Indonesia Nomor 2 Tahun 2012 tentang Pengawas Madrasah dan Pengawas PAI pada Sekolah adalah Guru Pegawai Negeri Sipil yang diangkat dalam jabatan fungsional Pengawas Satuan Pendidikan yang tugas, tanggungjawab, dan wewenangnya melakukan pengawasan akademik dan pengawasan manajerial pada sekolah. Pengawasan dalam konteks ini meliputi penyusunan program, pelaksanaan pembinaan, pemantauan, supervisi, evaluasi, dan pelaporan, serta pengambilan langkah tindak lanjut yang diperlukan. ${ }^{4}$ Pengawas sekolah berwenang: a) Memberi masukan, saran, dan bimbingan dalam penyusunan, pelaksanaan, dan evaluasi program pendidikan dan/atau pembelajaran kepada kepala sekolah, Kepala Kantor Kementerian Agama Kabupaten/Kota atau Kepala Kantor Wilayah Kementerian Agama Provinsi; b) Memantau dan menilai kinerja Kepala sekolah serta merumuskan saran tindak lanjut yang diperlukan; c) Melakukan pembinaan terhadap pendidik dan tenaga kependidikan di sekolah; dan d) Memberikan pertimbangan dalam penilaian pelaksanaan tugas, dan penempatan Kepala sekolah serta guru kepada Kepala Kantor Kementerian Agama Kabupaten/Kota.

Pengawasan terhadap sekolah umum dan Madrasah yang dilakukan oleh Kementerian Pendidikan maupun Kementerian Agama adalah dalam rangka pembinaan, pengembangan,

${ }^{3}$ Kementrian Agama RI, Pedoman Pelaksanaan Pemenuhan Beban Kerja Pengawas Madrasah (Jakarta: Direktorat Pendidikan Madrasah Direktorat Jendral Pendidikan Islam Kementrian Agama RI, 2014), 1.

${ }^{4}$ Ibid., 2. 
MA'ALIM: Jurnal Pendidikan Islam

Volume 1, Nomor 1, Juli 2020

perlindungan, peningkatan mutu dan pelayanan terhadap sekolah dan madrasah tersebut. Pengawasan tersebut lebih merupakan upaya untuk memberikan bimbingan, dorongan dan pengayoman bagi semua satuan pendidikan yang bersangkutan yang diharapkan terus menerus dapat meningkatkan mutu pendidikan maupun mutu pelayanannya. Pengawasan atau supervisi dilakukan terhadap penyelenggaraan pendidikan di sekolah umum dan madrasah untuk memperoleh gambaran menyeluruh mengenai pengelolaan sekolah atau madrasah yang meliputi aspek edukatif dan administrative.

Sebagai wujud pembinaan tenaga kependidikan dari pengawas Pendidikan Agama Islam adalah peningkatan kompetensi guru PAI di sekolah. Tuntutan tugas Pengawas Pendidikan Agama Islam untuk melaksanakan peningkatan pendidikan secara terarah, berencana, dan berkesinambungan salah satunya adalah dengan meningkatkan peranan dan tanggung jawab seorang guru. Konsekuensi adanya tuntutan terhadap kompetensi guru.

Guru adalah orang yang berperan langsung dalam proses belajar mengajar. Posisi dan peran strategis tersebut, membutuhkan kompetensi khusus yang mumpuni, sehingga guru benar-benar mampu menunjukkan kemampuan profesionalnya yang optimal. Guru yang professional adalah guru yang memiliki seperangkat kompetensi, baik yang menyangkut pengetahuan, ketrampilan, maupun perilaku yang harus dimiliki, dihayati, dan dikuasai oleh guru dalam melaksanakan tugas kepofesionalannya.

Pada penjajakan awal, peneliti mencoba menggali informasi dari pengawas pendidikan islam mengenai kompetensi guru PAI dan di dapatkan bahwa kompetensi guru masih banyak yang perlu di perbaiki. Maka dari itu kompetensi guru perlu ditingkatkan. Pengawas Pendidikan Agama Islam rutin melakukan kunjungan dan pelatihan untuk meningkatkan kompetensi guru PAI.

Berangkat dari latar belakang masalah tersebut, penulis ingin mengetahui upaya yang dilakukan oleh Pemerintah melalui Pengawas Pendidikan Agama Islam (PPAI) untuk meningkatkan kompetensi guru PAI.

\section{METODE}

Penelitian ini merupakan penelitian kualitatif. Jenis penelitian yang digunakan adalah studi kasus yaitu penelitian yang bertujuan untuk mempelajari secara intensif mengenai unit sosial tertentu yang meliputi individu, kelompok, institusi atau masyarakat. Dalam penelitian kasus ini akan dilakukan penggalian data secara mendalam dan menganalisis intensif faktor-faktor yang 
MA'ALIM: Jurnal Pendidikan Islam

Volume 1, Nomor 1, Juli 2020

terlibat di dalamnya. ${ }^{5}$ Sehingga dalam penelitian ini penulis melakukan dialog dengan subjek yang diteliti untuk memperoleh masukan berupa data-data lisan untuk kemudian melakukan pencatatan secara lengkap semua masukan yang diperoleh dari subjek tersebut. Data-data tersebut selanjutnya dideskripsi. ${ }^{6}$ Sehingga dalam penelitian ini mampu mengungkapkan informasi tentang apa yang mereka lakukan tentang fokus penelitian serta pengambilan data dengan menggunakan metode wawancara, observasi dan dokumentasi tentang Pengawas Pendidikan Agama Islam (PPAI) Kecamatan Sidoarjo Kabupaten Sidoarjo.

Sumber dalam penelitian ini meliputi informan kunci yaitu pengawas pendidikan agama islam (PPAI) Kecamatan Sidoarjo Kabupaten Sidoarjo, Selain itu juga ada informan-informan lain yang tidak kalah penting seperti Guru PAI di SMP Swasta wilayah Kecamatan Sidoarjo Kabupaten Sidoarjo dan mitra kerja Pengawas Pendidikan Agama Islam (PPAI) Kecamatan Sidoarjo Kabupaten Sidoarjo.

Peneliti melakukan wawancara dan obsrvasi pada orang-orang serta lokasi yang telah di tetapkan sebelumnya diantaranya Pengawas Pendidikan Agama Islam Kecamatan Sidoarjo Kabupaten Sidoarjo untuk mengetahui tentang kompetensi Guru PAI di SMP Swasta wilayah Kecamatan Sidoarjo Kabupaten Sidoarjo dan Guru PAI di SMP Swasta wilayah Kecamatan Sidoarjo Kabupaten Sidoarjo. Metode analisis datanya menggunakan model interaktif (alur) Miles dan Huberman yang mencakup reduksi data, display data, dan pengambilan kesimpulan atau verifikasi, sehingga data yang didapatkan mendalam.

\section{HASIL}

\section{Peran Pengawas Pendidikan Agama Islam (PPAI) dalam Meningkatkan Kompetensi Pedagogik Guru PAI}

Aspek-aspek ketahanan belajar siswa dilakukan dengan berbagai macam metodologi dan strategi pembelajaran. Hal ini dikarenakan keberhasilan siswa dalam belajar pendidikan agama Islam sangat ditentukan oleh strategi pembelajaran yang dilakukan oleh guru. Oleh karena itu, guru dituntut untuk mampu merancang rangkaian kegiatan-kegiatan yang diperlukan dalam proses kegiatan belajar yang sesuai dengan kebutuhan siswa dan tujuan pembelajaran. Sedangkan monitoring pengawas pendidikan agama islam melalui guru berkaitan dengan ketahanan belajar

\footnotetext{
${ }^{5}$ Yatim` Riyanto, Metodologi Penelitian Pendidikan (Surabaya: SIC, 2001), 24.

${ }^{6}$ Lexy J. Moleong, Metodologi Penelitian Kualitatif (Bandung: PT. Remaja Rosdakarya, 2009), 4.
} 
MA'ALIM: Jurnal Pendidikan Islam

Volume 1, Nomor 1, Juli 2020

siswa dilakukan dengan cara melihat hasil evaluasi guru. Sesuai hasil wawancara dengan pengawas sebagai berikut :

"Selalu melalukan evaluasi dan tindak lanjut berkaitan dengan ketahanan siswa." $(01 / \mathrm{W} / 16-\mathrm{X} / 17)$

Fungsi monitoring yang dilakukan oleh pengawas pendidikan agama Islam berkaitan dengan pengawasan akademik yang lain adalah standar mutu hasil belajar siswa. Pengawas melakukan pengukuran terhadap standar mutu dari hasil belajar.

Sesuai dengan pemaparan hasil wawancara menunjukkan bahwa pengawas melakukan kegiatan monitoring terhadap standar mutu dari hasil belajar siswa melalui isian laporan guru ke pengawas berkaitan dengan hasil belajar siswa dan problem untuk ditindaklanjuti. Melalui isian laporan yang diberikan guru, maka pengawas pendidikan agama Islam dapat mengetahui hasil belajar siswa sehingga dapat diketahui mutunya. Di dalam laporan isian yang dilakukan oleh guru juga diuraikan mengenai masalah yang dalami oleh guru dalam melakukan pembelajaran materi pendidikan agama Islam. Pencatatan masalah yang dialami oleh guru dalam pembelajaran materi pendidikan agama Islam dapat digunakan sebagai masukkan bagi pengawas pendidikan agama Islam untuk melakukan perbaikan dalam proses pembelajaran.

Kompetensi pedagogik yang dimiliki oleh guru berkaitan dengan kemampuan dalam pengelolaan peserta didik. Kemampuan dalam pengelolaan peserta didik dapat dilihat dari persiapan yang dilakukan oleh guru sebelum melakukan proses pembelajaran. Berdasarkan hasil wawancara menunjukkan ketiga informan melakukan persiapan dalam proses pembelajaran. Persiapan atau perencanaan adalah tahap awal yang harus dilalui oleh guru dalam pembelajaran. Pada tahap ini guru mempersiapkan segala sesuatu agar pembelajaran yang akan dilaksanakan dapat berjalan secara efektif dan efisien. Proses pembelajaran dikatakan efektif apabila penyampaian bahan pembelajaran sesuai dengan waktu yang tersedia. Sedangkan yang dimaksud dengan pembelajaran yang efisien adalah semua bahan pelajaran dapat dipahami siswa.

"Iya saya mempunyai persiapan tersendiri sebelum mengajar terutama berkaitan dengan media pembelajaran, tergantung materi yang di sampaikan, apabila materi itu bisa di praktekkan langsung saya menggunakan metode praktek langsung. (19/W/26-X/17)

Salah satu tugas pengawas pendidikan agama Islam terkait dengan pengawasan akademik adalah supervisi untuk meningatkan kinerja guru. Berdasarkan pemaparan hasil wawancara di atas menunjukkan supervisi yang dilakukan oleh pengawas dalam meningkatkan kinerja guru adalah 
MA'ALIM: Jurnal Pendidikan Islam

Volume 1, Nomor 1, Juli 2020

melakukan pendampingan, selain itu juga dilakukan supervisi atas kewajiban-kewajiban guru. Apabila muncul masalah pada saat guru menjalankan kegiatan belajar mengajar maka pengawas akan mengkomunikasikan dengan guru tersebut sehingga permasalahan dapat diselesaikan dengan baik. Pengawas juga mampu memberi arahan untuk peningkatan mutu dan kualitas dalam pengembangan kualitas pendidik terutama yang berkaitan dengan kompetensi guru pendidikan agama Islam.

"Biasanya saya melakukan kegiatan supervise kinerja guru dengan mendampingi guru ketika guru melakukan kewajiban nya dalam jangka waktu 1 bulan sekali. Hal ini yang menjadi program rutin supervise kepengawasan." (03/W/17-X/17)

Sedangkan untuk kegiatan supervisi pelaksanaan kurikulum/mata pelajaran dikemukakan oleh informan sebagai berikut:

"Seminimal mungkin saya lakukan secara intensifikasi dengan adanya pembelajaran yang berlangsung selama proses pembelajaran." (04/W/17-X/17)

Berdasarkan hasil wawancara menunjukkan bahwa supervisi pelaksanaan kurikulum adalah seminimal mungkin dilakukan secara intensifikasi dengan adanya pembelajaran yang berlangsung. Pengawasan yang dilakukan oleh pengawas pendidikan agama Islam terhadap pelaksanaan kurikulum/mata pelajaran adalah dengan datang ke sekolah dan mengamati proses pembelajaran yang sedang berlangsung. Pengawas dapat melihat isi/materi pelajaran kesesuaiannya dengan Kurikulum Tingkat Satuan Pendidikan (KTSP), silabus dan RPP yang disusun oleh satuan pendidikan. Pengawas pendidikan agama Islam akan memastikan pelaksanaan pembelajaran pendidikan agama Islam sesuai dengan tujuan pendidikan nasional.

"Saya selalu melakukan pendampingan secara langsung kepada guru dan memberi masukan kepada guru terkait dengan pelaksanaan kegiatan pembelajaran untuk memastikan isi pembelajaran sesuai dengan tujuan pendidikan.” (05/W/17-X/17)

Berdasarkan hasil wawancara di atas menunjukkan bahwa pengawas akan melakukan pendampingan dan memberi masukan kepada guru untuk memastikan pelaksanaan pembelajaran pendidikan agama Islam sesuai tujuan pendidikan nasional.

Pelaksanaan pembelajaran pendidikan agama Islam tidak hanya bersifat teoretis, namun juga dalam bentuk praktikum/atau studi lapangan. Supervisi terhadap pelaksanaan praktikum atau studi lapangan termasuk dalam tugas pengawasan akademik.

Petunjuk yang dilakukan pengawas pendidikan agama Islam tidak hanya sebatas pada kegiatan ekstrakurikuler, namun juga mencakup supervisi penggunaan media, alat bantu dan 
MA'ALIM: Jurnal Pendidikan Islam

Volume 1, Nomor 1, Juli 2020

sumber belajar di sekolah. Hasil wawancara dengan informan penelitian diperoleh informasi sebagai berikut:

"Kegiatan pembelajaran menggunakan media dilakukan oleh guru yang mempunyai kemampuan menggunakan media tersebuut, sedangkan bagi yang guru yang belum memiliki kemampuan diupayakan pembelajaran secara intensif." (06/W/17-X/17)

Media pembelajaran merupakan segala sesuatu dalam bentuk fisik yang digunakan untuk mengkomunikasikan materi pelajaran kepada peserta didik sehingga proses pembelajaran dapat berlangsung efektif, efisien, dan menyenangkan. Melalui media pembelajaran akan memudahkan peserta didik dalam menerima dan memahami materi pelajaran. Peran pengawas dalam melakukan supervisi penggunaan media, alat bantu dan sumber belajar di sekolah adalah dengan memberikan pembelajaran kepada guru yang kurang memilii kemampuan menggunakan media pembelajaran. Pengawas pendidikan dapat memberikan petunjuk media pembelajaran yang sesuai dengan karakteristik peserta didik dan materi pendidikan Islam. Hasil wawancara dengan informan penelitian menunjukkan bahwa guru dapat menggunakan video, media gerak, dan media hidup untuk alat pembelajaran pendidikan agama Islam.

Materi ajar yang disampaikan kepada siswa akan lebih dipahami apabila guru menggunakan media pembelajaran. Berdasarkan hasil wawancara terhadap ketiga informan guru diperoleh informasi sebagai berikut:

"Iya, karena dengan menggunakan media pembelajaran memudahkan siswa untuk memahami materi yang di sampaikan.” (18/W/24-X/17)

"Iya, seperti dalam bab zakat menggunakan post card jadi setiap siswa ikut andil dalam pembagian zakat." (19/W/26-X/17)

Berdasarkan hasil wawancara dengan ketiga informan menunjukkan adanya penggunaan media dalam proses pembelajaran. Media pembelajaran merupakan segala sesuatu dalam bentuk fisik yang digunakan untuk mengkomunikasikan materi pelajaran kepada peserta didik sehingga proses pembelajaran dapat berlangsung efektif, efisien, dan menyenangkan. Melalui media pembelajaran akan memudahkan peserta didik dalam menerima dan memahami materi pelajaran. Berdasarkan hasil wawancara dapat diketahui dua orang informan menggunakan media pembelajaran berupa LCD (Liquid Cristal Display) sedangkan seorang informan menggunaan media pembelajaran tergantung materi yang akan disampaikan keada siswa.

Di dalam proses pembelajaran, guru, staff dan kepala sekolah memiliki peran yang penting dan strategis dalam menjalankan proses pembelajaran kepada peserta didik. Oleh karena itu, guru, 
MA'ALIM: Jurnal Pendidikan Islam

Volume 1, Nomor 1, Juli 2020

staff dan kepala sekolah perlu diberikan suatu program bimbingan karir karena hal tersebut merupakan salah satu strategi organisasi dalam meningkatkan kinerja dan profesionalitas guru. Program tersebut dapat berupa in service training. In service training merupakan suatu usaha pelatihan atau pembinaan yang memberi kesempatan kepada seseorang yang mendapat tugas jabatan tertentu untuk mendapatkan pengembangan karir. Pengawas pendidikan agama Islam berperan juga dalam mellakukan supervisi kegiatan inservice training bagi kepala sekolah, guru dan staff lainnya. Hasil wawancara terkait supervisi pelaksanaan kegiatan inservice training sebagai berikut:

"Pengawas mengikuti rapat bersama seluruh staf dan guru guru di lembaga yang bersangkutan terkait dengan pelaksanaan inservice training yang di adakan oleh pengawas. " (07/W/17-X/17)

Berdasarkan hasil wawancara di atas menunjukkan bahwa peran pengawas dalam supervisi kegiatan inservice training melalui rapat yang diadakan bersama kepala sekolah dan guru. Melalui rapat tersebut pengawas dalam membimbing dan memberi masukan mengenai program inservice training. Rapat merupakan kegiatan yang sering digunakan oleh pengawas pendidikan dalam melakukan supervisi terhadap pengawasan manajerial (administrasi dan manajemen sekolah) sebagaimana juga yang dilakukan pada saat mmelakukan supervisi pada guru, staff dan Kepala Sekolah terkait dengan kegiatan antar sekolah binaan serta pelaksanaan kegiatan inovasi terhadap sekolah. Kegiatan inovasi pada proses pembelajaran di sekolah pada dasarnya untuk meningkatkan kinerja dan kreatifitas segenap komponen sekolah untuk mewujudkan kegiatan belajar mengajar yang lebih menarik bagi peserta didik.

Pada dasarnya fungsi pengawas pendidikan agama Islam baik di sekolah umum maupun di madrasah salah satunya adalah sebagai alat untuk memperbaiki proses belajar mengajar pendidikan agama Islam di sekolah umum dan penyelenggaraan pendidikan di madrasah baik dari segi teknis edukatif maupun teknis administrasi. Fungsi tersebut menunjukkan bahwa kegiatan administrasi yang diselenggarakan oleh pihak sekolah termasuk dalam fokus pengawasan. Supervisi terhadap kegiatan penyelenggaraan administrasi sekolah bersinergi dengan bagian Tata Usaha (TU) dan wakil kepala sekolah. Melalui fungsi pengawasan diharapkan penyelenggaraan administrasi sekolah lebih efektif dan efisien.

Penilaian yang dhasilkan oleh pengawas pendidikan agama Islam sebagai bagian dari tugas pokok dan fungsinya dapat memberikan informasi yang dapat digunakan untuk memberi masukan 
MA'ALIM: Jurnal Pendidikan Islam

Volume 1, Nomor 1, Juli 2020

terhadap keseluruhan komponen yang terdapat di sekolah. Tugas pokok penilaian meliputi: penilaian, pengolahan dan analisis data atas hasil belajar/bimbingan siswa dan kaitannya dengan faktor guru; mengumpulkan dan mengolah data sumberdaya pendidikan, proses pembelajaran/bimbingan, lingkungan sekolah yang berpengaruh terhadap perkembangan hasil belajar/bimbingan siswa; melaksanakan analisis komprehensif hasil penilaian sebagai bahan untuk melakukan inovasi pendidikan di sekolah binaan.

Peran pengawas melakukan penilaian terhadap proses pembelajaran dan bimbingan siswa oleh guru berdasarkan hasil wawancara sebagai berikut:

"Biasanya saya melakukan pendampingan terhadap guru di dalam kelas bersama dengan kepsek untuk mengetahui bagaimana proses pembelajaran siswa oleh guru tersebut." (08/W/18-X/17)

Pengawas pendidikan agama Islam memiliki tugas pengawasan akademik, salah satunya penilaian terhadap proses pembelajaran dan bimbingan. Sesuai dengan hasil wawancara di atas menunjukkan dalam melakukan penilaian terhadap proses pembelajaran dan bimbingan dengan cara melakukan kunjungan kelas sesuai dengan jadwal yang telah ditetapkan sebelumnya. Tujuan kunjungan kelas adalah pengawas ingin memperoleh data mengenai keadaan sebenarnya selama guru mengajar. Dengan data tersebut, pengawas pendidikan agama Islam berbincang-bincang dengan guru tentang kesulitan yang dihadapi dalam proses pembelajaran.

Di dalam melakukan kunjungan ke sekolah, pengawas pendidikan Islam juga melakukan penilaian terhadap sistem nilai yang dilakukan oleh guru pada siswanya dengan cara:

"Melakukan pengecekan kisi-kisi soal berdasarkan indikator yang di buat oleh guru dalam RPP apakah mengacu kepada K1-K4 atau tidak.” (09/W/18-X/17)

Berdasarkan hasil wawancara di atas menunjukkan bahwa penilaian terhadap sistem nilai yang dilakukan oleh guru pada siswanya dilakukan oleh pengawas pendidikan Islam berdasarkan pengecekan kisi-kisi soal berdasarkan indikator yang dibuat oleh guru dalam RPP dengan melihat kesesuaiannya berdasarkan K1-K4. Apabila terjadi kesesuaian maka tujuan pembelajaran akan mudah tercapai. Disamping itu, tercapaianya tujuan pembelajaran perlu didukung oleh inovasi pembelajaran guru di kelas, dengan tujuan kegiatan belajar dapat lebih menarik sehingga siswa mudah dalam memahami materi pelajaran. 
MA'ALIM: Jurnal Pendidikan Islam

Volume 1, Nomor 1, Juli 2020

\section{Peran Pengawas Pendidikan Agama Islam (PPAI) Dalam Meningkatkan Kompetensi Profesional Guru PAI}

Kesesuaian proses pembelajaran yang dilakukan oleh guru dengan RPP (Rencana Pelaksanaan Pembelajaran) begitu penting karena RPP sendiri dibuat ooleh guru untuk membantunya dalam mengajar agar sesuai dengan standar kompetensi dan kompetensi dasar. Menurut Permendikbud Nomor 65 Tahun 2013 tentang Standar Proses, Rencana Pelaksanaan Pembelajaran (RPP) adalah rencana kegiatan pembelajaran tatap muka untuk satu pertemuan atau lebih. RPP dikembangkan dari silabus untuk mengarahkan kegiatan pembelajaran peserta didik dalam upaya mencapai Kompetensi Dasar, karena dalam proses pembelajaran seringkali guru juga mengalami hambatan seperti siswa yang tidak mempunyai minatuntuk belajar dan sarana prasarana yang belum terpenuhi di sekolah.

Proses pembelajaran yang dilakukan oleh guru sesuai dengan RPP yang telah dibuat sebagaimana hasil wawancara berikut:

"Iya, karena dari pengawas meninjau ketepatan RPP dengan yang di sampaikan." $(10 / \mathrm{W} / 18-\mathrm{X} / 17)$

Pengawas berperan dalam melakukan penilaian terhadap inovasi yang dilakukan oleh guru dengan cara:

"Saya memberikan saran guru membuat inovasi dengan mencari di media internet atau media apapun yang sesuai dengan materi yang di sampaikan oleh guru yang sekiranya membuat siswa senang dan semangat untuk belajar di dalam kelas." (10/W/18-X/17)

Sesuai dengan hasil wawancara di atas menunjukkan pengawas akan melakukan penilaian dan memberikan saran sesuai dengan materi yang disampaikan oleh guru. Sebagaimana dalam Surat Keputusan Menteri Negara Pendayagunaan Aparatur Negara (SK MENPAN) nomor 118 Th. 1996 tentang jabatan fungsional pengawas sekolah dan angka kreditnya, dinyatakan bahwa pengawas sekolah adalah Pegawai Negeri Sipil (PNS) yang diberi tugas, tanggung jawab dan wewenang secara penuh oleh pejabat yang berwenang untuk melakukan pengawasan di sekolah dengan melakukan penilaian dan pembinaan dari segi teknis pendidikan dan administrasi pada satuan pendidikan prasekolah, pendidikan dasar dan menengah.

Sementara cara dilakukan oleh pengawas untuk melakukan penilaian terhadap kegiatan peningkatan kemampuan profesi guru adalah: 
MA'ALIM: Jurnal Pendidikan Islam

Volume 1, Nomor 1, Juli 2020

"Saya melakukan penilaian dengan menyarankan penerimaan tunjangan bagi guru $20 \%$ di pergunakan untuk pengembangan diri atau PKB (pengembangan keprofesian berkelanjutan) guna meningkatkan kemampuan profesi guru." (11/W/18-X/17)

Sesuai dengan hasil wawancara di atas dengan memberikan saran tunjangan bagi guru $20 \%$ di pergunakan untuk pengembangan diri atau PKB (pengembangan keprofesian berkelanjutan). Melalui pengembangan keprofesian berkelanjutan akan berimplikasi pada peningkatan mutu sumber daya manusia di lingkungan sekolah. Untuk mengetahui ada atau tidaknya peningkatan mutu sumber daya manusia di lingkungan sekolah maka pengawas melakukan penilaian dengan melihat kreatifitas dan inovasi dari masing-masing guru yang ada di sekolah.

Melakukan kegiatan pembinaan kepada guru dalam hal mengembangkan kemampuan guru mengembangkan media dan alat bantu pembelajaran maka pengawas akan melakukan musyawarah dengan guru mata pelajaran. Di dalam musyawarah tersebut, pengawas pendidikan agaa Islam akan memberikan pembinaan dan bimbingan sehingga memudahkan guru untuk meningkatkan kemampuan dan menggunakan media pembelajaran. Upaya pembinaan yang dilakukan oleh pengawas dalam memberikan pembinaan dan contoh dalam kegiatan inovasi pembelajaran dalam kelas kepada guru melalui focus group discussion dan pengawas akan menyampaikan mengenai inovasi yang dapat dilakukan oleh guru dalam proses pembelajaran. Pengawas akan memberikan pembinaan dan contoh kepada guru dalam strategi pembelajaran/bimbingan yang efektif pada siswa di sekolah sebagaimana hasil wawancara berikut:

"Menggunakan strategi pembelajaran yang variatif sesuai dengan kemampuan siswa, kondisi kelas, kompetensi siswa, alat yang di perlukan dan keperluan lain yang berhubungan dengan kebutuhan KBM." (13/W/19-X/17)

Berdasarkan hasil wawancara di atas menunjukkan bahwa peran pengawas pendidikan agama Islam dalam memberikan pembinaan dan contoh kepada guru dalam strategi pembelajaran yang efektif melalui pembinaan menggunakan strategi pembelajaran yang variatif sesuai dengan kemampuan siswa, kondisi kelas, kompetensi siswa, alat yang di perlukan dan keperluan lain yang berhubungan dengan kebutuhan. Hal ini dikarenakkan melalui pembelajaran yang variatif akan membuat siswa lebih tertarik dalam belajar dan memudahkan siswa untuk memahami materi pelajaran. Sedangkan strategi pengawas memberikan pembinaan guna meningkatkan kompetensi profesional guru dikemukakan pada hasil wawancara berikut:

"Strateginya adalah mengikuti kegiatan MGMP secara aktif dan memberikan motivasi dorongan untuk banyak membaca lingkungan dan membaca buku yang bermanfaat yang 
MA'ALIM: Jurnal Pendidikan Islam

Volume 1, Nomor 1, Juli 2020

berhubungan langsung dengan keprofesionalannya dan melalui pendidikan, loka karya dan sebagainya." $(14 / \mathrm{W} / 19-\mathrm{X} / 17)$

Pemaparan hasil wawancara di atas menunjukkan peran pengawas pendidikan agama Islam dalam meningkatkan kompetensi profesional guru melalui kegiatan MGM (Musyawarah Guru Mata Pelajaran) dan melalui pendidikan serta loka karya. Pembinaan yang dilakukan oleh pengawas pendidikan agama Islam tidak hanya berfokus pada peningkatan profesionalisme guru namun juga pembinaan pada guru terkait dengan pelaksanaan penilaian proses dan hasil belajar di kelas dan membina guru guna meningkatkan kompetensi pribadi, sosial dan pedagogik sebagaimana hasil wawancara berikut:

Diharapkan guru memberikan nilai sesuai dengan kurikulum yang berlaku sedangkan ranah aspek yang dinilai sesuai dengan kurikulum yang sedang dilakukan.

"Melakukan komunikasi secara intensif dan di lakukan rencana tindak lanjut yang di temukan pengawas di saat penilaian terhadap guru dan menganalisa evaluasi diri." $(15 / \mathrm{W} / 19-\mathrm{X} / 17)$

Hasil wawancara menunjukkan peran pengawas dalam pembinaan pada guru terkait dengan pelaksanaan penilaian proses dan hasil belajar di kelas adalah memastikan guru memberikan nilai sesuai dengan kurikulum yang berlaku dengan didasarkan pada kompetensi inti dan kompetensi dasar. Sedangkan, strategi yang dilakukan oleh pengawas dalam membina guru guna meningkatkan kompetensi pribadi, sosial dan pedagogik dilakukan oleh pengawas pendidikan agama Islam dengan cara komunikasi intensif dan dilakukan rencana tindak lanjut yang ditemukan pengawas disaat penilaian dan evaluasi.

Tugas pokok pelaporan dan tindak lanjut meliputi tugas: melaporkan perkembangan dan hasil pengawsan kepada Kepala Pendidikan Kabupaten/Kota, Propinsi dan/atau Nasional, melaporkan perkembangan dan hasil pengawasan ke sekolah binaannya, Komite sekolah dan stakeholder lainnya; menetapkan langkah-langkah alternative tindak lanjut untuk program pengawasan selanjutnya. Untuk pelaksanaan tugas tersebut, pengawas satuan pendidikan harus terlebih dahulu menyusun program kerja kepengawasan untuk program tahunan danprogram setiap semester pada sekolah yang dibinanya. Berdasarkan hasil wawancara diperoleh informasi sebagai berikut:

"Pelaporan di lakukan setelah adanya penilaian dan apabila di temukan kekurangan oleh guru maka akan di lakukan pembimbingan terhadap guru tersebut agar lebih baik lagi." (16/W/23-X/17) 
MA'ALIM: Jurnal Pendidikan Islam

Volume 1, Nomor 1, Juli 2020

Sesuai dengan hasil wawancara di atas menunjukkan pengawas pendidikan agama Islam membuat pelaporan ataupun tindak lanjut terkait dengan kinerja guru dalam melaksanakan pembelajaran dengan cara melakukan pembimbingan kepada guru. Pengawas pendidikan agama Islam akan melakukan diskusi atau sharing dengan guru baik pada saat kujunngan ke sekolah maupun ketika Musyawarah Guru Mata Pelajaran. Melalui diskusi, pengawas akan memberi petunjuk atau saran terhadap kekurangan-kekurangan yang dimiliki guru dengan tujuan peningkatan kinerja. Sedangkan pelaporan atau tindak lanjut terkait temuan kemauan belajar siswa dengan cara membuat instrumen yang diisi ketika melakukan kunjungan ke sekolah.

Pelaporan yang dilakukan oleh pengawas pendidikan agama Islam juga terkait dengan hasil inovasi pembelajaran guru di kelas. Sesuai dengan hasil wawancara berikut:

"Kreatifitas, aktifitas dan efektivitas yang sangat diperlukan pada KBM (Kegiatan Belajar Mengajar) yang disesuaikan dengan waktu." (17/W/23-X/2017)

Berdasaran hasil wawancara di atas menunjukkan bahwa pengawas pendidikan agama Islam terkait dengan hasil inovasi pembelajaran guru di kelas dengan melihat kreatifitas dan efektifitas inovasi yang dilakukan oleh guru di kelas dalam proses pembelajaran. Setiap kegiatan pengawasan yang dilakukan oleh pengawas akan dilakukan pelaporan atau tindak lanjutnya. Pelaporan merupakananalisa pengawas untuk memberdayakan, mengaktifkan, memperbaiki dan menyempurnakan pada saat kegiatan belajar mengajar.

Persiapan dalam proses pembelajaran dapat dilakukan oleh guru dengan mempelajari terlebih dahulu setiap materi yang akan diajarkan oleh siswa sebagaimana hasil wawancara berikut.

"Iya, untuk mengetahui apa saja yang akan disampaikan di dalam kelas dan strategi apa yang akan di gunakan di dalam pengajaran." (18/W/24-X/17)

"Perlu, kerena setiap materi biasanya perlu untuk penambahan materi, di dalam MGMP guru dituntut untuk memahami materi secara meluas biar tidak ketinggalan materi baru." $(19 / \mathrm{W} / 26-\mathrm{X} / 17)$

Berdasarkan hasil wawancara di atas menuunjukkan bahwa salah satu persiapan yang dilakukan oleh guru adalah dengan mempelajari materi pelajaran yang akan disampaikan kepada siswa. Hal ini dilakukan agar guru memiliki penguasaan materi dan mampu menyampaikannya dengan baik kepada para siswa. Disamping itu, guru juga harus mengikuti perkembangan referensi terbaru berkaitan dengan ilmu yang hendak diajarkan, hal ini dilakukan agar pengetahuan yang 
MA'ALIM: Jurnal Pendidikan Islam

Volume 1, Nomor 1, Juli 2020

diberikan kepada siswa merupakan hal yang baru dan up-to-date. Hasil wawancara dengan ketiga informan penelitian diperoleh informasi sebagai berikut:

Iya, karena sekarang kurikulumnya baru K13 jadi untuk sumbernya juga berbeda tapi yang di sampaikan tetap sama, berbedanya sekarang di tambahi dengan menggunakan internet dll." (19/W/26-X/17)

Iya, perkembangan referensi terbaru sangat di perlukan untuk menambah pengetahuan siswa." (20/W/27-X/17)

Berdasarkan hasil wawancara menunjukkan ketiga informan mengikuti perkembangan referensi terbaru berkaitan dengan ilmu yang hendak diajarkan. Guru sendiri memiliki wadah berupa MGMP (Musyawarah Guru Mata Pelajaran) yang dapat digunakan sebagai sarana saling bertukar informasi mengenai perkembangan ilmu sehingga bermanfaat dalam proses pembelajaran di kelas.

Di dalam proses pembelajaran setelah tahap persiapan adalah pelaksanaan pembelajaran. ada tahap pelaksanaan, aktivitas belajar mengajar berpedoman pada persiapan pengajaran yang dibuat. Pemberian bahan pelajaran disesuaikan dengan urutan yang telah di program secara sistematis dalam tahap persiapan. Berdasarkan hasil wawancara dengan ketiga informan penelitian menunjukkan pada saat pelaksanaan pembelajaran guru menggunakan sumber belajar tertentu. Penggunaan sumber belajar tertentu disesuaikan dengan materi yang dajarkan kepada siswa. Selain itu, di dalam penggunaan sumber belajar tidak hanya didasarkan pada referensi buku tertentu yang diwajibkan oleh pemerintah, namun juga menggunakan referensi dari buku lain. Hal ini dilakukan oleh ketiga informan untuk memperdalam materi ajar yang disampaikan kepada siswa.

Media pembelajaran merupakan segala sesuatu dalam bentuk fisik yang digunakan untuk mengkomunikasikan materi pelajaran kepada peserta didik sehingga proses pembelajaran dapat berlangsung efektif, efisien, dan menyenangkan. Melalui media pembelajaran akan memudahkan peserta didik dalam menerima dan memahami materi pelajaran. Berdasarkan hasil wawancara dapat diketahui dua orang informan menggunakan media pembelajaran berupa LCD (Liquid Cristal Display) sedangkan seorang informan menggunaan media pembelajaran tergantung materi yang akan disampaikan keada siswa.

Proses pembelajaran di sekolah agar lebih menarik dan mudah dipahami oleh siswa memerlukan inovasi dari guru. Guru harus memiliki metode tersendiri agar proses pembelajaran di kelas lebih menarik. Berdasarkan hasil wawancara diperoleh informasi sebagai berikut: 
MA'ALIM: Jurnal Pendidikan Islam

Volume 1, Nomor 1, Juli 2020

"Iya, karena semakin menarik metode yang digunakan akan membuat siswa tertarik untuk semangat dalam belajar.” (18/W/24-X/17)

Berdasarkkan hasil wawancara di atas menunjukkan ketiga infoorman dalam penelitian ini memiliki metode tersendiri agar proses pembelajaran di kelas lebih menarik dan mudah diterima oleh siswa. Inovasi yang dilakukan oleh guru dalam metode pembelajaran dapat menyebabkan siswa menjadi bersemangat dalam belajar. Sedangkan untuk mengetahui keberhasilan dalam proses pembelajaran, maka guru dapat melakukan evaluasi terkait hasil belajar. Hasil wawancara dengan ketiga informan penelitian sebagai berikut:

"Iya, dengan mengadakan ulangan harian ataupun tanya jawab berupa kuis." (18/W/24$\mathrm{X} / 17)$

"Iya, evaluasi di lakukan dengan ulangan harian setiap akhir materi yang di sampaikan." (20/W/27-X/17)

Hasil wawancara ketiga informan memiliki kesamaan yaitu melakukan evaluasi terkait dengan proses dan hasil mengajar. Evaluasi harian dapat dilakukan dengan cara ulangan harian atau tanya jawab dengan siswa. Evaluasi dapat dijadikan sebagai tolak ukur keberhasilan proses belajar mengajar. Sedangkan metode yang digunakan untuk mengaktualisasikan berbagai potensi yang dimiliki oleh siswa dengan menggunakan pendekatan scientific dan discovery learning. Meskipun tidak ada kesamaan metode, namun proses pembelajaran yang dilakukan oleh guru sesuai dengan RPP yang telah dibuat sebagaimana hasil wawancara berikut:

"Iya, sesuai karena dari pengawas RPP harus di sama agar sinkron dengan yang di sampaikan." (19/W/26-X/17)

Kesesuaian proses pembelajaran yang dilakukan oleh guru dengan RPP (Rencana Pelaksanaan Pembelajaran) begitu penting karena RPP sendiri dibuat ooleh guru untuk membantunya dalam mengajar agar sesuai dengan standar kompetensi dan kompetensi dasar. Menurut Permendikbud Nomor 65 Tahun 2013 tentang Standar Proses, Rencana Pelaksanaan Pembelajaran (RPP) adalah rencana kegiatan pembelajaran tatap muka untuk satu pertemuan atau lebih. RPP dikembangkan dari silabus untuk mengarahkan kegiatan pembelajaran peserta didik dalam upaya mencapai Kompetensi Dasar, karena dalam proses pembelajaran seringkali guru juga mengalami hambatan seperti siswa yang tidak mempunyai minat untuk belajar dan sarana prasarana yang belum terpenuhi di sekolah. 
MA'ALIM: Jurnal Pendidikan Islam

Volume 1, Nomor 1, Juli 2020

Hal ini dikarenakan ilmu pengetahuan bersifat dinamis yang selalu mengalami perkembangan sehingga setiap guru diharuskan melakukan pembaharuan referensi untuk kebaruan terhadap ilmu-ilmu yang diajarkan kepada siswa. Profesionalisme guru dalam menjalankan tugasnya juga dapat dilihat dari penggunaan materi ajar sesuai dengan kurikulum yang ditetapkan. Berdasarkan hasil wawancara diperoleh informasi sebagai berikut:

"Iya, sekolah menggunakan kurikulum K13 namun pengembangan materi yang di sampaikan lebih banyak dan luas. ” (18/W/24-X/17)

"Iya, materi ajar harus sesuai dengan kurikulum sekolah K13, dan akan di lakukan pengawasan rutin tentang hal tersebut." (20/W/27-X/17)

Hasil wawancara di atas menunjukkan ketiga informan sepakat bahwa materi ajar yang digunakan oleh guru menggunakan materi ajar sesuai dengan kurikulum di sekolahyaitu kurikulum 2013 (K-13). K-13 menekankan pada penyempurnaan pola pikir peserta didik dari yang semula pembelajaran berpusat pada guru beralih berpusat pada peserta didik, pembelajaran yang semula satu arah menjadi lebih interaktif dan pembelajaran didorong untuk mengikuti konteks dunia nyata. Oleh karena itu, guru juga harus memiliki metode pembelajaran yang memudahkan siswa untuk menyerap dan memahami materi. Pemilihan metode pembelajaran yang tepat menunjukkan kemampuan guru dalam penguasaan materi pembelajaran secara luas, hal ini dikarenakan penggunaan metode tidak terlepas dari materi yang akan diajarkan kepada siswa. Berdasarkan hasil penelitian menunjukkan terdapat beberapa metode yang digunakan oleh guru pendidikan agama Islam agar siswa mudah menyerap dan memahami materi yang terdiri dari halaqah, discovery learning, inquiry, problem solving, diskusi dan demonstrasi. Sedangkan untuk mengetahui tingkat pemahaman siswa maka upaya dilakukan oleh guru sebagai berikut:

"Iya, kuis/tes kecil kadang perlu dilakukan untuk mengetahui tingkat pemahaman siswa secara langsung." (18/W/24-X/17)

"Kuis dilakukan di awal dan di tengah-tengah tujuannya supaya siswa tidak rame, dan agar mereka paham apa yang saya sampaikan." (19/W/26-X/17)

“Iya, biasanya berupa pertanyaan-pertanyaan ringan dan singkat.” (20/W/27-X/17)

Berdasarkan hasil wawancara di atas menunjukkan bahwa uaya yang dilakukan oleh guru untuk mengetahui tingkat pemahaman siswa terhadap materi yang diajarkan oleh guru adalah melalui pemberian kuis atau pertanyaan kepada siswa setelah pemberian materi. Disamping itu, ketiga informan juga melakukan inovasi dalam penerapan konsep-konsep keilmuan dalam 
MA'ALIM: Jurnal Pendidikan Islam

Volume 1, Nomor 1, Juli 2020

kehidupan sehari-hari, seperti menerapkan sholat dhuha dan dhuhur berjamaah serta metode diskusi di kelas. Konsep-konsep yang terkait antar mata pelajaran juga dijelaskan oleh guru pendidikan agama Islam. Guru akan menjelaskan mengenai konsep antar mata pelajaran agar memudahkan siswa memahami melalui metode ceramah yang disampaikan oleh guru ketika kegiatan belajar mengajar di kelas.

Guru sebagai seorang pendidik juga harus mampu menggalo potensi siswa, karena itu guru dapat mendorong siswa untuk mengikuti kompetisi di luar sekolah. Berdasarkan hasil wawancara dengan ketiga informan penelitian diperoleh informasi sebagai berikut:

"Sangat mendorong, misal ada kompetisi PAIS antar sekolah." (19/W/26-X/17)

"Iya, selalu diberi motivasi untuk mendorong keinginan siswa mengikuti sebuah kompetisi." (20/W/27-X/17)

Sesuai dengan pemaparan hasil wawancara di atas menunjukkan bahwa guru pendidikan agama Islam yang menjadi informan penelitian berusaha mengembangkan kemampuan siswa dengan mengikutsertakan pada kompetisi antar sekolah. Hal ini juga didukung oleh pihak sekolah seperti yang dipaparkan pada hasil wawancara berikut.

Sangat mendukung, karena dapat mendidik siswa agar menggunakan kemmpuan berfikirnya secara luas." (18/W/24-X/17)

“Sangat mendukung, kita selalu melatih setiap hari setiap ada jam kosong. ”(19/W/26-X/17)

"Selalu, sekolah selalu mendukung dan melengkapi apa yang di butuhkan siswa tersebut, membantu dengan melatih/mengasah bakat siswa tersebut." (20/W/27-X/17)

Hasil wawancara di atas menunjukkan bahwa pihak sekolah turut mendukung siswa berpartisipasi dalam kompetisi di luar sekolah, hal ini bisa dilihat dari guru yang mendampingi dan mendukung secara penuh apabila siswa mengikuti kegiatan kompetisi di luar sekolah.

\section{DISKUSI}

\section{Peran Pengawas Pendidikan Agama Islam dalam meningkatkan kompetensi guru PAI}

Pengawas Sekolah memiliki peran yang strategis dalam proses pendidikan yang bermutu di sekolah. Dalam konteks ini peran Pengawas sekolah meliputi pemantauan, supervisi, evaluasi, pelaporan, dan tindak lanjut pengawasan yang harus dilakukan secara berkesinambungan (PP Nomor 19 tahun 2005, pasal 55). Peran tersebut berkaitan dengan tugas pokok Pengawas sekolah dalam melakukan supervisi akademik dan supervisi manajerial serta pembinaan, pemantauan, dan 
MA'ALIM: Jurnal Pendidikan Islam

Volume 1, Nomor 1, Juli 2020

penilaian. Peran Pengawas sekolah dalam pembinaan setidaknya sebagai teladan bagi tenaga pendidik di madrasah dan rekan kerja yang serasi dengan pihak madrasah dalam memajukan madrasah binaannya. Peran pengawasan tersebut dilaksanakan dengan pendekatan supervisi yang bersifat ilmiah, klinis, manusiawi, kolaboratif, artistik, interpretatif, dan berbasis kondisi sosial budaya. Pendekatan ini bertujuan untuk meningkatkan mutu pembelajaran. ${ }^{7}$ Menurut PP No. 19 tahun 2005 pasal 55 bahwa peran pengawas sekolah meliputi pemantauan, supervisi, evaluasi, pelaporan dan tindak lanjut pengawas yang harus dilakukan secara teratur dan berkesinambungan. ${ }^{8}$ Peran tersebut berkaitan dengan tugas pokok pengawas dalam melakukan supervisi manajerial dan akademik, serta pemantauan, pembinaan dan penilaian

Menurut Peraturan Menteri Negara Pendayagunaan Aparatur Negara \& Reformasi Birokrasi Nomor 21 tahun 2010 tentang Jabatan fungsional Pengawas Sekolah dan Angka Kreditnya, Tugas pokok pengawas sekolah adalah melaksanakan tugas pengawasan akademik dan menejerial pada satuan pendidikan yang meliputi penyusunan program pengawasan, pelaksanaan pembinaan, pemantauan pelaksanaan 8 (delapan) Standar Nasional pendidikan, penilaian, pembimbingan dan pelatihan professional guru evaluasi hasil pelaksanaan program pengawasan dan pelaksanaan tugas pengawasan di daerah khusus. ${ }^{9}$

Di dalam dunia pendidikan supervisi yang dilakukan merupakan bentuk pengawasan terhadap kegiatan akademik yang berupa proses belajar mengajar, pengawasan terhadap guru dalam mengajar, pengawasan terhadap murid yang belajar dan pengawasan terhadap situasi yang menyebabkannya. Dengan kata lain, dalam supervisi ada proses pelayanan untuk membantu atau membina guru-guru. Pembinaan ini bertujuan untuk perbaikan atau peningkatan kemampuan kemudian di transfer kedalam perilaku mengajar sehingga tercipta situasi belajar mengajar yang lebih baik, yang akhirnya juga meningkatkan pertumbuhan peserta didik. Supervisi dilakukan oleh pengawas pendidikan sebagaimana diatur dalam Surat Keputusan Menteri Negara Pendayagunaan Aparatur Negara (SK MENPAN) nomor 118 Th. 1996 tentang jabatan fungsional pengawas sekolah dan angka kreditnya.

\footnotetext{
7 Direktorat Pendidikan Madrasah, Pedoman Pembinaan Pengawas Madrasah (Jakarta: Direktorat Jendral Pendidikan Islam Kementrian Agama RI, 2014), 6.

${ }^{8}$ Peraturan Pemerintah RI. Nomor 19 tahun 2005 tentang Standar Nasional Pendidikan.

${ }^{9}$ Peraturan Menpan dan Reformasi Birokrasi Nomor 21 tahun 2010 tentang Jabatan Pengawas Sekolah dan Angka Kreditnya (Jakarta: Menteri Pendayagunaan Aparatur Negara, 2010)
} 
MA'ALIM: Jurnal Pendidikan Islam

Volume 1, Nomor 1, Juli 2020

Di dalam pengawasan terhadap pendidikan agama Islam dilakukan oleh Pengawas Pendidikan Agama Islam. Pengawas Pendidikan Agama Islam (PPAI) adalah pegawai Negeri Sipil di lingkungan Kementerian Agama yang diberi tugas, tanggung jawab dan wewenang terhadap pelaksanaan Pendidikan Agama Islam di sekolah umum dan penyelenggara pendidikan di madrasah dengan melakukan penilaian dan pembinaan dari segi teknis pendidikan dan administrasi pada satuan pendidikan prasekolah, pendidikan dasar dan menengah. ${ }^{10}$ Peran pengawasan oleh pengawas pendidikan agama Islam di SMP Swasta Wilayah Kecamatan Sidoarjo Kabupaten Sidoarjo bertujuan untuk meningkatkan mutu pendidikan, membimbing dan memfasilitasi guru dalam pengembangan kompetensinya, memberi motivasi guru agar menjalankan tugasnya secara efektif dan membantu guru membina potensi peserta didik agar berkembang secara optimal.

Fungsi pengawasan yang dilakukan oleh pengawas pendidikan agama Islam terdiri dari pengawasan akademik dan administrasi (pengawasan). Tugas pengawasan akademik, menitikberatkan pengamatan pada masalah yang langsung berada dalam lingkup pembelajaran yang dilakukan guru untuk membantu siswa ketika sedang dalam proses belajar. ${ }^{11}$ Pengawasan akademik berkaitan dengan membina dan membantu guru dalam meningkatkan kualitas proses pembelajaran/bimbingan dan kualitas hasil belajar siswa. Sedangkan pengawasan administrasi, menitikberatkan pengamatan pada aspek-aspek administrasi sebagai lingkungan belajar yang berfungsi mendukung terlaksananya pembelajaran. Pengawasan akademik membina dan membantu guru pendidikan agama Islam dalam pembelajaran misalnya membina dalam proses pembelajaran agar dapat meningkatkan kualitas hasil belajar siswa, sedangkan manajerial yaitu membina dan menilai kepala sekolah dan guru dalam pengelolaan sekolah serta membantu/membimbing program sekolah dari awal hingga hasilnya.

Kompetensi didefinisikan sebagai pengetahuan, ketrampilan, dan nilai-nilai yang direfleksikan dalam kebiasaan berfikir dan bertindak. Kompetensi tersebut akan terwujud dalam bentuk penguasaan pengetahuan dan perbuatan secara profesional dalam menjalankan fungsi sebagai guru. ${ }^{12}$

\footnotetext{
${ }^{10}$ Depag RI, Pedoman Rekrutmen Calon Pengawas (Jakarta: Dirjen Kelembagaan Agama Islam, 2004), 1 ${ }^{11}$ Zaenal Aqib, standar pengawas sekolah/madrasah, (Bandung : Yrama Widya, 2009), 87-88.

${ }^{12}$ Muhammad Rahman, Sofan Amri, Kode etik Profesi Guru (Jakarta: Prestasi Pustaka, 2014), 65
} 
MA'ALIM: Jurnal Pendidikan Islam

Volume 1, Nomor 1, Juli 2020

Kemudian, berdasarkan Undang-undang Nomor 14 Tahun 2005 tentang Guru dan Dosen pada bab IV Pasal 10 ayat 91, kompetensi yang harus dimiliki oleh guru, yaitu kompetensi pedagogik, kompetensi kepribadian, kompetensi sosial, dan kompetensi profesi.

Pengawas juga berperan dalam meningkatkan kompetensi pedagogik pada guru pendidikan agama Islam agar dapat menjalankan perannya sebagai pendidik agama sehingga hasil belajar siswa sesuai dengan yang diharapkan. Berdasarkan Undang-Undang Nomor 14 Tahun 2005 tentang Guru dan Dosen pada bab IV Pasal 10 ayat 91 menjelaskan bahwa kompetensi pedagogik adalah kemampuan dalam pengelolaan peserta didik. ${ }^{13}$ Pengawas pendidikan agama Islam dapat membantu sekolah dalam meningkatan kompetensi pedagogik melalui beberapa cara seperti supervisi dalam perencanaan pembelajaran, kemampuan dalam proses dan hasil belajar siswa, kemampuan memanfaatkan sumber-sumber belajar, kemampuan membina potensi siswa. Supervisi yang dilakukan oleh pengawas pendidikan agama Islam mampu meningkatan kemampuan pedagogik guru seperti melakukan perencanaan sebelum proses pembelajaran, mempelajari ulang setiap materi sebelum mengajar, mengikuti perkembangan referensi terbaru berkaitan dengan ilmu yang hendak diajarkan, menggunakan sumber belajar tertentu dalam proses pembelajaran, menggunakan referensi buku tertentu selain buku yang di wajibkan oleh pemerintah, menggunakan media pembelajaran dalam kegiatan belajar mengajar, merancang atau memiliki metode tersendiri agar proses pembelajaran di kelas agar lebih menarik dan mudah diterima oleh anak didik, dan mampu mengaktualisasikan berbagai potensi yang dimiliki siswa.

Kompetensi profesional yaitu kemampuan yang harus dimiliki guru dalam perencanaan dan pelaksanaan proses pembelajaran. Guru mempunyai tugas untuk mengarahkan kegiatan belajar peserta didik untuk mencapai tujuan pembelajaran. Untuk itu guru dituntut mempu menyampaikan bahan pelajaran. Guru harus selalu meng-update, dan menguasai materi pembelajaran yang disajikan.

Dalam menyampaikan pembelajaran, guru mempunyai peranan dan tugas sebagai sumber materi yang tidak pernah kering dalam mengelola proses pembelajaran. Kegiatan mengajarnya harus disambut oleh peserta didik sebagai suatu seni pengelolaan proses pembelajaran yang diperoleh melalui latihan, pengalaman, dan kemauan belajar yang tidak pernah putus.

Kompetensi profesional merupakan kemampuan penguasaan materi pembelajaran secara luas dan mendalam yang meliputi: a) konsep, struktur, dan metode keilmuan/teknologi/seni yang

\footnotetext{
${ }^{13}$ Momon Sudarma, Profesi Guru dipuji,dikritisi, dan dicaci, 133.
} 
MA'ALIM: Jurnal Pendidikan Islam

Volume 1, Nomor 1, Juli 2020

menaungi/koheren dengan materi ajar, b) materi ajar yang ada dalam kurikulum sekolah. c) hubungan konsep antar mata pelajaran terkait, d) penerapan konsep-konsep keilmuan dalam kehidupan sehari-hari, e) kompetisi secara profesional dalam konteks global dengan tetap melestarikan nilai dan budaya nasional. ${ }^{14}$

Pengawas pendidikan agama Islam juga berperan dalam meningkatan kompetensi profesional guru. Kompetensi profesional merupakan kemampuan penguasaan materi pembelajaran secara luas dan mendalam. ${ }^{15}$ Hasil penelitian menunjukkan bahwa kemampuan guru pendidikan agama Islam sudah baiik dalam penguasaan materi pembelajaran. Hal ini bisa dilihat dari kemampuan guru dalam melakukan prmbaharuan referensi, menggunakan materi ajar sesuai dengan kurikulum sekolah,menjelaskan kepada siswa terkait konsep antar mata pelajaran, melakukan evaluasi dengan menggunakan kuis atau tes kecil untuk mengetahui pemahaman siswa terhadap materi yang diajarkan guru, dan melakukan inovasi dalam melakukan penerapan konsepkonsep keilmuan dalam kehidupan sehari-hari. Kompetensi profesional yang dimiliki oleh guru pendidikan agama Islam tidak terlepas dari peran pengawas pendidikan agama Islam yang melakukan pendampingan bagi guru dalam menyusun RPP dan monitoring terhadap kegiatan belajar mengajar di kelas. Pengawas mampu memberikan petunjuk, bagaimana proses belajar mengajar menggunakan kurikulum berbasis kompetensi, serta bagaimana mengaktifkan siswa dalam setiap pembelajaran. Supervisi yang dilakukan oleh pengawas dalam meningkatkan kompetensi profesional guru dengan melakukan pembinaan dalam penguasaanmateri pembelajaran, pendampingan membuat perencanaan program pembelajaran, prosedur pelaksanaan pembelajaran dan penilaian hasil pembelajaran.

\section{KESIMPULAN}

Peran pengawas pendidikan agama Islam dalam meningkatkan kompetensi pedagogik guru PAI di SMP Swasta Wilayah Kecamatan Sidoarjo Kabupaten Sidoarjo melalui beberapa cara seperti supervisi dalam perencanaan pembelajaran, kemampuan dalam proses dan hasil belajar siswa, kemampuan memanfaatkan sumber-sumber belajar, kemampuan membina potensi siswa.

Peran pengawas pendidikan agama Islam dalam meningkatkan kompetensi profesional guru PAI di SMP Swasta Wilayah Kecamatan Sidoarjo Kabupaten Sidoarjo melalui beberapa cara

\footnotetext{
${ }^{14}$ Momon Sudarma, Profesi Guru Dipuji Dikritisi dan Dicaci (Jakarta: PT. RajaGrafindo Persada, 2013$), 133$. ${ }^{15}$ Ibid
} 
MA'ALIM: Jurnal Pendidikan Islam

Volume 1, Nomor 1, Juli 2020

yaitu melakukan pendampingan bagi guru dalam menyusun RPP dan monitoring terhadap kegiatan belajar mengajar di kelas. Pengawas mampu memberikan petunjuk, bagaimana proses belajar mengajar menggunakan kurikulum berbasis kompetensi, serta bagaimana mengaktifkan siswa dalam setiap pembelajaran

Sesuai dengan kesimpulan yang dikemukakan maka saran dalam penelitian ini adalah: 1) bagi pengawas hendaknya dapat meningkatkan frekuensi kunjungan ke sekolah-sekolah secara kontinue dan berkesinambungan untuk menjalankan tugas supervisi. Hal ini dikarenakan pengawas memiliki peran yang penting dalam peningkatan mutu pendidikan di suatu sekolah, 2) bagi pihak sekolah dapat membantu dalam memberikan fasilitas atau sarana dan prasarana berupa media pembelajaran yang mampu menunjang proses pembelajaran yang lebih menarik dan memudahkan siswa dalam memahami materi ajar, 3) bagi kementerian agama hendaknya dapat meningkatkan pembinaan keprofesian berkelanjutan bagi pengawas melalui pendidikan dan latihan, workshop dan kegiatan peningkatan kualitas kepengawasan perlu dilaksanakan secara berkala dan berkesinambungan untuk peningkatan kompetensi pengawas. Hal ini dikarenakan pengawas berperan penting dalam peningkatan mutu pendidikan di suatu sekolah.

\section{DAFTAR PUSTAKA}

Aqib, Zaenal. 2009. Standar Pengawas Sekolah/Madrasah. Bandung : Yrama Widya.

Departemen Agama RI. 2005. Profesionalisme Pelaksanaan Pengawasan Pendidikan. Jakarta: DIRJEND Kelembagaan Agama Islam.

DEPAG RI. 2004. Pedoman Rekrutmen Calon Pengawas. Jakarta: DIRJEND Kelembagaan Agama Islam.

Direktorat Pendidikan Madrasah Direktorat Jendral Pendidikan Islam Kementrian Agama RI.

Kementrian Agama RI. 2012. Pedoman Pelaksanaan Pemenuhan Beban Kerja Pengawas Madrasah. Jakarta.

Moleong, Lexy J. 2009. Metodologi Penelitian Kualitatif. Bandung: PT. Remaja Rosdakarya.

Miles, Mattew B. dan Huberman, A. 1992. Michael. Analisis Data Kualitatif, Terj. Tjetjep Rohendi Rohidi. Jakarta: UI Press.

Peraturan Menteri Pendidikan Nasional RI No. 12 Tahun 2007 tentang Standar Pengawas Sekolah/Madrasah. 2007. Jakarta: Menteri Pendidikan Nasional. 
MA'ALIM: Jurnal Pendidikan Islam

Volume 1, Nomor 1, Juli 2020

Peraturan Pemerintah RI. Nomor 19 tahun 2005 tentang Standar Nasional Pendidikan

Peraturan Menpan dan Reformasi Birokrasi Nomor 21 tahun 2010 tentang Jabatan Pengawas Sekolah dan Angka Kreditnya

Riyanto, Yatim. 2001. Metodologi Penelitian Pendidikan. Surabaya: SIC.

Sudarma, Momon. 2013. Profesi Guru Dipuji Dikritisi dan Dicaci. Jakarta: PT. RajaGrafindo Persada.

Undang-Undang Republik Indonesia Nomor 20 Tahun 2003 tentang Sistem Pendidikan Nasional. Jakarta:PT armas Duta Jaya. 